\title{
Screening of white-rot fungi manganese peroxidases: a comparison between the specific activities of the enzyme from different native producers
}

\author{
Juho Järvinen*, Sanna Taskila, Ritva Isomäki and Heikki Ojamo
}

\begin{abstract}
In this study manganese peroxidase (MnP) enzymes from selected white-rot fungi were isolated and compared for potential future recombinant production. White-rot fungi were cultivated in small-scale in liquid media and a simplified process was established for the purification of extracellular enzymes.

Five lignin degrading organisms were selected (Bjerkandera sp., Phanerochaete (P.) chrysosporium, Physisporinus (P.) rivulosus, Phlebia (P.) radiata and Phlebia sp. Nf b19) and studied for MnP production in small-scale. Extracellular MnP activity was followed and cultivations were harvested at proximity of the peak activity. The production of MnPs varied in different organisms but was clearly regulated by inducing liquid media components $(\mathrm{Mn} 2+$, veratryl alcohol and malonate). In total 8 different MnP isoforms were purified.

Results of this study reinforce the conception that MnPs from distinct organisms differ substantially in their properties. Production of the extracellular enzyme in general did not reach a substantial level. This further suggests that these native producers are not suitable for industrial scale production of the enzyme. The highest specific activities were observed with MnPs from P. chrysosporium (200 U mg-1), Phlebia sp. Nf b19 (55 U mg-1) and P. rivulosus (89 $\mathrm{U}$ mg-1) and these MnPs are considered as the most potential candidates for further studies. The molecular weight of the purified MnPs was estimated to be between 45-50 kDa.
\end{abstract}

Keywords: White-rot fungi, Manganese peroxidase, Lignin degradation, Lignocellulose, Enzyme purification

\section{Introduction}

At present lignocellulose is a major raw material for forestry, pulp and paper industry and the emerging second generation biofuel production. Among cellulose and hemicellulose, lignin is a major component of lignocellulosic biomass and largely responsible for its strength. Inside the Northern coniferous forest belt the importance of lignin utilization is stressed in wood-based biorefineries due to high amounts of lignin in softwoods (Li et al. 2009).

Lignin is a heterogeneous, branched and complex polymer consisting of phenylalanine-derived aromatic subunits (Whetten \& Sederoff 1995). Because of its recalcitrance, lignin complicates the utilization of biomass

\footnotetext{
* Correspondence: juho.jarvinen@oulu.fi
Bioprocess Engineering Laboratory, Department of Process and

* Correspondence: juho.jarvinen@oulu.fi

Environmental Engineering, University of Oulu, P. O. Box 4300, Oulu Fl-90014, Finland
}

polysaccharides in biorefineries and increases the energy consumption in mechanical pulping (Jiang et al. 2008a). In nature one group of organisms, the basidiomycetous fungi, are able to effectively degrade lignin by employing a family of lignin degrading enzymes. These organisms can be divided into wood-colonizing white-rot fungi and soil litter-decomposing fungi. Fungal attack on lignin is attributed to certain secreted nonspecific oxidoreductases, which produce low molecular weight mediators able to intrude recalcitrant biopolymers. The family of extracellular ligninolytic enzymes typically includes lignin peroxidases (LiP, EC 1.11.1.14), laccases (EC 1.10.3.2), manganese peroxidases (MnP, EC 1.11.1.13), versatile peroxidases (VP, EC 1.11.1.16) and other accessory enzymes.

Out of these enzymes MnP is thought to play the most crucial role in lignin degradation, as it is found in all lignin degrading fungi white-rot fungi. This heme protein 
belongs to the commonly occurring class II peroxidase group in basidiomycetous fungi and has a highly specific Mn2+ -binding site. In the binding site of classical long MnPs there are three amino-acid residues (two Glu and one Asp) while several fungal Mn2+ -oxidizing enzymes with an additional tryptophan residue on the enzyme surface have been found. These enzymes are called VPs or hybrid MnPs, bearing resemblance to LiPs and able to perform oxidation though long-range electron transfer as well. The evolution of these class II peroxidases appears to be closely related to each other and even consistent with the sharp decline in coal accumulation rate during the Permo-Carboniferous period. Lignin is the main precursor for coal (Hofrichter et al. 2010; Floudas et al. 2012). MnP catalyses the oxidation of $\mathrm{Mn} 2+-$ ions to highly reactive Mn3+-ions. Chelated Mn3+ in turn act as low molecular weight mediators that are able to attack phenolic structures. $\mathrm{MnP}$ is able to cause substantial depolymerization if lignin in in vitro biomass treatments (Hofrichter 2002; Hofrichter et al. 2001; Maijala et al. 2008).

Potential applications for MnP include biomechanical pulping, pulp bleaching, dye decolorization, bioremediation and production of high-value chemicals from residual lignin from biorefineries and pulp and paper side-streams (Maijala et al. 2008; Moreira et al. 2003; Moreira et al. 2001; Xu et al. 2010a and 2010b; Paice et al. 1993; Susla et al. 2008; Hofrichter et al. 1998; Sack et al. 1997). Applications of MnP are limited due to slow growth and low productivity of native enzyme producers and lack of an efficient recombinant production process (Hofrichter 2002; Jiang et al. 2008a).

The production of lignolytic enzymes and its regulation has been intensively studied in various lignin degrading fungi (Bonnarme \& Jeffries 1990; Hakala et al. 2006; Jiménez-Tobon et al. 2003; Kamitsuji et al. 2004; Lankinen et al. 2005; Martínez et al. 1996; Moilanen et al. 1996; Nuske et al. 2002; Perie \& Gold 1991; Palma et al. 2000; Petruccioli et al. 2009; Schneegab et al. 1997; Swamy \& Ramsay 1999; Steffen et al. 2002; Susla et al. 2008; Silva et al. 2008; Sklenar et al. 2010; Singh et al. 2011; Taboada-Puig et al. 2011; Vares et al. 1995; Wang et al. 2001; Wang et al. 2008) and novel bacterial strains (Bharagava et al. 2009; Mishra \& Thakur 2010; Yadav et al. 2011). Recombinant production has been studied in filamentous fungi (Conesa et al. 2000; Irie et al. 2001; Li et al. 2001; Mayfield et al. 1994; Stewart et al. 1996), yeasts (Jiang et al. 2008a), bacterial (Whitwam \& Tien 1996) and insect (Johnson et al. 1992; Pease et al. 1991) hosts with successful production but modest yields of active enzyme. MnP from $P$. chrysosporium has been the target of most recombinant studies, which however suffer from unsuccessful posttranslational protein modification and the need for exogenous heme in high concentrations (Jiang et al. 2008a).
Furthermore, industrially robust enzymes need to have high stability in demanding process conditions which promotes the need for screening novel enzymes and enzyme modification. Multiple crystal structures and molecular models based on gene sequences have been published for MnP and VP (e.g. Sundaramoorthy et al. 1997; Sutherland et al. 1997 and Moreira et al. 2005). The effects of disulfide bonds and calcium-ions on the stability of $\mathrm{MnP}$ have been studied by Reading et al. (2001) and Sutherland et al. (1997), respectively. As a result of enzyme modification, a mutant MnP with one additional disulfide bond had increased stability in alkaline ( $\mathrm{pH}$ 8) conditions (Reading et al. 2001). Another strategy is to screen for native MnPs with improved properties regarding thermostability, specific activity or pH optimum and stability (Petruccioli et al. 2009 and Urek \& Pazarlioglu 2004). Increased specific activity (U mg-1 protein) of the selected protein would also increase the profitability of the recombinant process. Independent of the strategy the bottleneck is the establishment of an efficient recombinant production.

The aim of the present study was to screen MnPs from promising candidates of lignin degrading fungi for future recombinant production. Specific activities of MnPs were determined after cultivation and purification procedures. Isoforms of $\mathrm{MnP}$ from different organisms differ substantially and screening for novel MnP enzymes is beneficial for designing applications and developing a production process capable of producing the enzyme at an economically feasible cost. However high-throughput screening is challenging due to low enzyme yields and diverse regulation of $\mathrm{MnP}$ isoenzymes in different native hosts.

\section{Materials and methods}

\section{Fungi and culture conditions}

White-rot fungi strains Bjerkandera sp. BEL LLP4 (D-00810) and P. radiata Hatakka \& Pirhonen strain 79 (ATCC 64658, D-84236) were ordered from the VTT Technical Research Centre of Finland culture collection, Finland. Strains P. chrysosporium (ATCC 24725, DSM 6909), Phlebia sp. Nf b19 (ATCC 201144, DSM 11239) and P. rivulosus T241i (DSM 14618) were ordered from the Leibniz institute DSMZ-German collection of microorganisms and cell cultures GmbH, Germany. Phlebia $s p$. Nf b19 was originally identified as Nematoloma frowardii species but reassigned to the family Corticiaceae and genus Phlebia based on a molecular level study by Hildén et al. (2008).

The fungi were maintained on solid agar plates. The agars used were $0.4 \%$ potato $2 \%$ dextrose agar (Difco, USA) for $P$. radiata, $3 \%$ malt extract-peptone agar (Merck, Germany) for P. chrysosporium, Phlebia sp. Nf b19 and $P$. rivulosus and 3\% malt agar (Difco, USA) for Bjerkandera sp. The plates were incubated for 2-10 days 
until covered with mycelium. Plates were stored at $4^{\circ} \mathrm{C}$ and replated monthly.

The inocula were prepared by suspending the mycelia from one plate to sterile $0.9 \%(\mathrm{w} / \mathrm{v})$ Sodium chloride. One plate was used to inoculate two parallel fungi cultivations.

The production of extracellular MnP in each organism was followed in two parallel cultivations in $1 \mathrm{~L}$ shake flasks containing $300 \mathrm{~mL}$ of liquid media with $90 \mathrm{rpm}$ agitation. Cultivation temperatures were $37^{\circ} \mathrm{C}$ for $P$. chrysosporium, $25^{\circ} \mathrm{C}$ for Phlebia sp. $N f$ b19 and $28^{\circ} \mathrm{C}$ for all other whiterot fungi strains. $P$. radiata was grown in low-nitrogen ADMS medium pH 4.5 (Hatakka \& Uusi-Rauva 1983) with $1 \%$ glucose, $0.05 \%(\mathrm{w} / \mathrm{v})$ Tween 80 and $1 \mathrm{mM}$ veratryl alcohol (VA, 3,4-dimethoxybenzyl alcohol). Supplements $180 \mu \mathrm{M} \mathrm{Mn} 2+$ and $10 \mathrm{mM}$ Sodium malonate were added on the 4th day. P. rivulosus was grown in low-nitrogen ADMS medium pH 4.5 (Hatakka \& Uusi-Rauva 1983) with $1 \%$ glucose and $0.05 \%(\mathrm{w} / \mathrm{v})$ Tween 20 . Supplements $24 \mu \mathrm{M} \mathrm{Mn} 2+$ and $0.36 \mathrm{mM}$ VA were added on the 4th day. P. chrysosporium was grown in Kirk's medium $\mathrm{pH} 4.5$ (Urek \& Pazarlioglu 2004; Tien \& Kirk 1988 and Bonnarme \& Jeffries 1990) with $1 \%$ glucose and $0.05 \%(w / v)$ Tween 80. Supplements $728 \mu \mathrm{M} \mathrm{Mn} 2+$ and $0.36 \mathrm{mM}$ VA were added on the 4th day. Bjerkandera sp. was grown in Kirk's medium pH 4.5 (Palma et al. 2000) with $1 \%$ glucose and $0.05 \%$ (w/v) Tween 80, $235 \mu \mathrm{M} \mathrm{Mn2+} \mathrm{and} 0.36 \mathrm{mM}$ VA. Phlebia sp. Nf b19 was grown in a glucose-yeast extract medium pH 4.5 (Nuske et al. 2002) with $0.5 \%$ glucose, $0.03 \%$ yeast extract and $200 \mu \mathrm{M} \mathrm{Mn2+}$. Cultivations were continued until extracellular MnP activity was detected and it started to decline.

\section{Sampling}

$1 \mathrm{~mL}$ samples were taken every $24 \mathrm{~h}$ from each flask. Samples were centrifuged to remove cellmass $(16000 \times$ $\mathrm{g}, 4^{\circ} \mathrm{C}$ ). The supernatant was used for determination of $\mathrm{MnP}$ activity and glucose and total protein concentrations. All of the cultivations were performed in duplicate and the presented results are average values.

\section{Enzyme assay and analytical procedures}

Glucose concentration during cultivation was determined using the YSI 2700 SELECT $^{\mathrm{TM}}$ (YSI limited, UK, Hampshire) biosensor.

$\mathrm{MnP}$ activity was determined spectrophotometrically at $270 \mathrm{~nm}$ by following the formation of $\mathrm{Mn} 3+-$ malonate complex at pH 4.5 in $50 \mathrm{mM}$ sodium malonate buffer with $0.5 \mathrm{mM} \mathrm{MnSO}$. The reaction was initiated by adding $\mathrm{H} 2 \mathrm{O} 2$ to the final concentration of $0.1 \mathrm{mM}$ (Wariishi et al. 1992). The reaction was followed for $30 \mathrm{sec}$ at room temperature. $\triangle$ Abs min-1 was converted to $\mathrm{U}$ L-1 using an extinction coefficient of $11590 \mathrm{M}-1 \mathrm{~cm}-1$. Genesys
10UV spectrometer (Thermo Scientific, USA) was used in all the measurements with semi-micro 1.4 mL UV quartz cuvettes (Sigma-aldrich, Germany)

Total protein was determined with the Bio-Rad protein Assay (USA) using bovine serum albumin (BSA) as a standard. Measurements were made with Genesys 10UV spectrometer (Thermo Scientific, USA) at $595 \mathrm{~nm}$ wavelength.

Protein expression and purity was followed using sodium dodecyl sulfate polyacrylamide gel electrophoresis (SDS-PAGE) with silver nitrate staining. Ready-made BioRad (USA) ready GelTM precast gels (12\% Tris- $\mathrm{HCl}$ ) were used with Bio-Rad (USA) prestained low range protein standards.

\section{Purification of manganese peroxidases}

Cellmass was separated from the culture fluids by centrifugation at $16000 \times \mathrm{g}, 4^{\circ} \mathrm{C}$ (Avanti $\mathrm{J}$ series centrifuge, Beckman Coulter Inc, USA). Supernatant was then filtered through a Whatman grade 1 filter paper $(11 \mu \mathrm{m}$, Whatman, UK). Filtrate was then stored in $-20^{\circ} \mathrm{C}$ until further processing.

Concentration of the culture fluids from the screening cultivations was done by using Vivaspin 20 centrifugal concentrators with $10 \mathrm{kDa}$ cut-off membranes (GE Healthcare, USA and Sartorius Stedim Biotech, Germany). Crude culture liquids were concentrated approximately tenfold by volume. Megafuge 1.0R (Heraeus, England) was used for centrifugation at $3400 \times g, 4^{\circ} \mathrm{C}$. Diafiltration was performed in Vivaspin tubes by filtering $20 \mathrm{mM}$ Bis-TRISpropane buffer ( $\mathrm{pH}$ 6.2) through the membrane (three times the volume of the concentrate).

ÄKTAavantTM liquid chromatography system (GE Healthcare, USA) equipped with a strong anion exchange column (HiScreenTM CaptoTM Q, GE Healthcare, USA) was used for protein separation. The outflow was monitored at two wavelengths: $280 \mathrm{~nm}$ for protein and $405 \mathrm{~nm}$ for hemeprotein detection. The column was first equilibrated with $20 \mathrm{mM}$ Bis-TRIS-propane buffer $(\mathrm{pH}$ 6.2) and proteins were eluted with a linear gradient of $0-1 \mathrm{M} \mathrm{NaCl}$ in the same buffer. $2 \mathrm{~mL}$ fractions were collected during the elution phase. The fractions were assayed for $\mathrm{MnP}$ activity and total protein. Peaks were pooled separately and stored at $-20^{\circ} \mathrm{C}$.

\section{Results}

\section{$\mathrm{MnP}$ production in selected white-rot fungi}

The activity (U l-1) of MnP enzyme produced and the time period it took to reach the maximal activity varied greatly between the selected white-rot fungi. A unifying trend of accelerated glucose consumption just before and during $\mathrm{MnP}$ production was observed in these batch cultivations (Figure 1A \& 1B). The $\mathrm{MnP}$ peak timing and maximal activity varied between 7-21 days and 

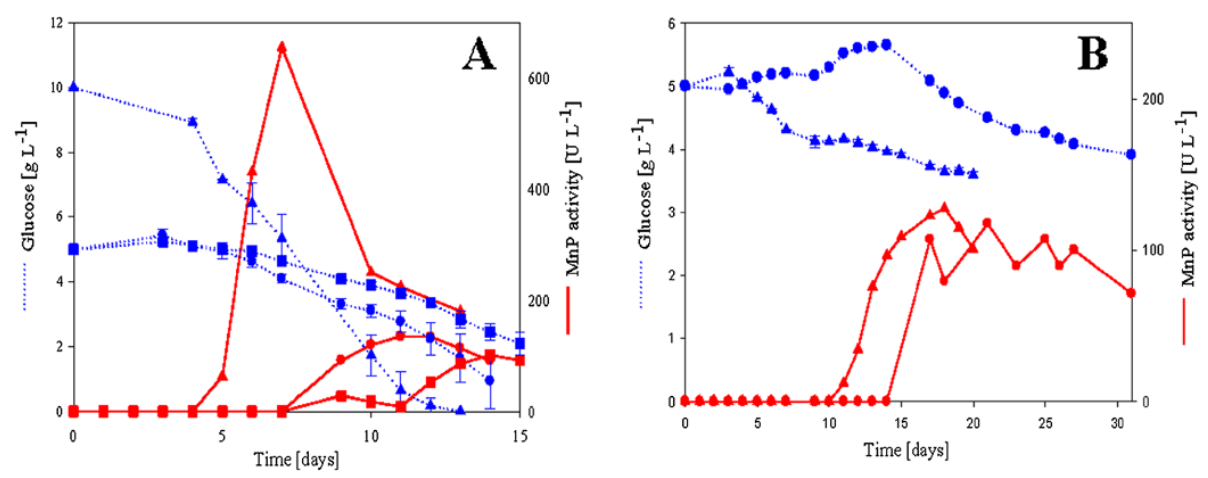

Figure 1 Glucose consumption (dotted line) and MnP activity (solid line) by white-rot fungi during $300 \mathrm{~mL}$ batch cultivations. Each strain was cultivated in specific conditions and media described in the materials section. Values are calculated averages of two parallel cultivations. Standard deviation of MnP activity in parallel cultures is on average $\pm 40 \mathrm{UL}^{-1}$. Bjerkandera sp. (A, blue and red triangles),

Phanerochaete chrysosporium (A, blue and red circles), Physisporinus rivulosus (A, blue and red squares), Phlebia radiata (B, blue and red triangles), Phlebia sp. Nf b19 (B, blue and red circles). Harvesting point is designated by the end of sampling.

100-800 U 1-1, respectively. Fastest growing white-rot fungus in these experiments was Bjerkandera $s p$., which also produced the highest activities. However, the MnP activity of Bjerkandera $s p$. increased and subsequently declined very sharply. These cultures were harvested 6 days after the MnP activity peak, which may have resulted in inactivated protein and lowered specific activity.

\section{Purification of $\mathrm{MnP}$ isoenzymes from crude culture filtrates}

Crude culture filtrates were concentrated and purified in a rapid purification scheme described in the materials section. Based on the SDS-PAGE gels (Figure 2A-E) MnP was the predominant protein produced in most of the cultures and highly purified in the pooled anion exchange fractions (Figures 3, 4, 5, 6, 7). In the Phlebia sp. Nf b19 culture supernatant and concentrate, a larger enzyme (around $70 \mathrm{kDa}$ ) was the predominant one. Based on the size, this is probably a laccase. Loss of MnP activity was high during the purification process. $\mathrm{MnP}$ activity was lost especially in the concentration step, but this is not relevant for the determination of specific activity. The role of enzyme inactivation in the purification procedure is minimized due to low kept temperatures $\left(4^{\circ} \mathrm{C}\right)$ during each step. After the strong anion exchange (Mono Q column) one MnP isoenzyme for Bjerkandera sp. (Figure 3), Phlebia sp. $N f$ b19 (Figure 7) and P. rivulosus (Figure 5); two $\mathrm{MnP}$ isoenzymes for $P$. chrysosporium (Figure 4) and possibly three isoenzymes for $P$. radiata (Figure 6) were detected. All of the MnP active fractions showed absorbance peaks in the $280 \mathrm{~nm}$ wavelength for protein and in the $405 \mathrm{~nm}$ wavelength for the heme containing protein. Wavelenght $405 \mathrm{~nm}$ could easily be used for selecting fractions likely to show $\mathrm{MnP}$ activity. $\mathrm{MnP}$ proteins were eluted between 175 and $320 \mathrm{mM} \mathrm{NaCl}$ concentrations.
The molecular weight of the MnPs was between 45 and $50 \mathrm{kDa}$ (Table 1). Specific activities of the MnPs were calculated on the basis of the activity measurements and measured total protein in the pooled active fractions. $P$. chrysosporium $\mathrm{MnP} 1$ had the highest specific activity (200 U mg-1). The second highest specific activity was observed for $P$. rivulosus (89 U mg-1). Phlebia sp. Nf b19 MnP had the specific activity of $55 \mathrm{U}$ mg1. Rest of the MnP isoenzymes had a specific activity below $40 \mathrm{U}$ mg-1 (Table 1 ).

Preliminary results of in vitro enzymatic processing of milled pinewood sawdust with crude MnP concentrates showed up to $17 \%$ (data not shown) decrease in Klason lignin content and benefitted from the use of cooxidants (Tween 80 and glutathione) in some cases.

\section{Discussion}

These results show that a simplified purification process is capable of producing comparable specific activity results for the screening of novel MnP enzymes. Culture supernatant concentration and anion exchange chromatography using a Mono Q column was enough to purify the enzyme to a high degree. Although the initial enzyme amounts were low and the losses during concentration were quite high, these results provide a basis for enzyme ranking. Based on these results there are significant differences in the specific activities of MnP enzymes from different white-rot fungi. Out of the white-rot fungi used in this study $P$. chrysosporium, $P$. rivulosus and Phlebia sp. Nf b19 MnPs were the most promising. For P. rivulosus and Phlebia sp. Nf b19 these results are also consistent with the $\mathrm{MnP}$ activity and protein absorbance $(280 \mathrm{~nm})$ ratio in anion exchange chromatography (Table 1). The MnP activity (U 1-1) of Bjerkandera sp. had come down over $70 \%$ at the point of harvesting. If the lost activity is accounted as inactivated $\mathrm{MnP}$ in the total protein 


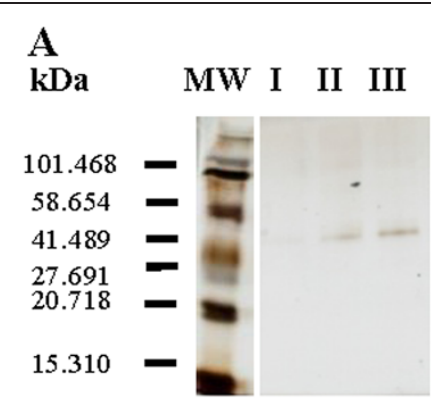

C $\mathrm{kDa}$

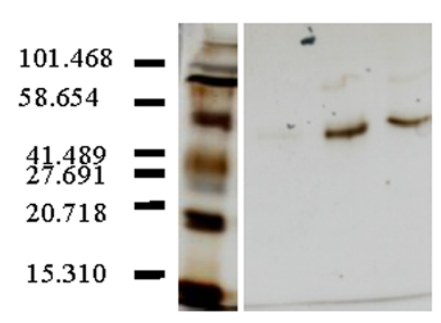

\section{E}

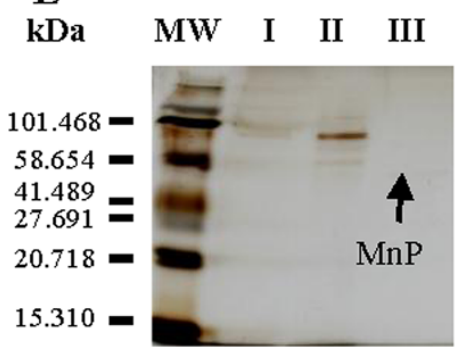

B

kDa MW I II III IV

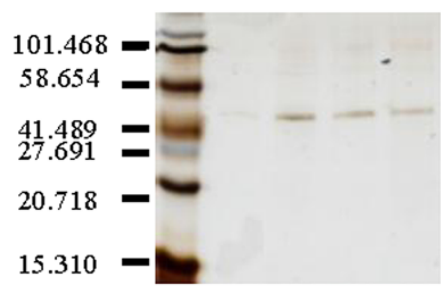

D

kDa MW I II III IV V

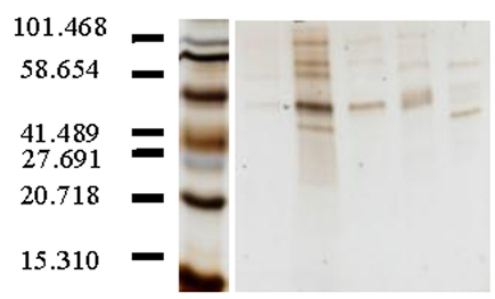

Figure 2 (A-E) Silver stained SDS-PAGE gels in corresponding order from the purification process with molecular weight protein standards (MW), crude extracellular fluids (I), concentrated samples (II) and MnP isoenzymes from MonoQ anion exchange column (III-V).

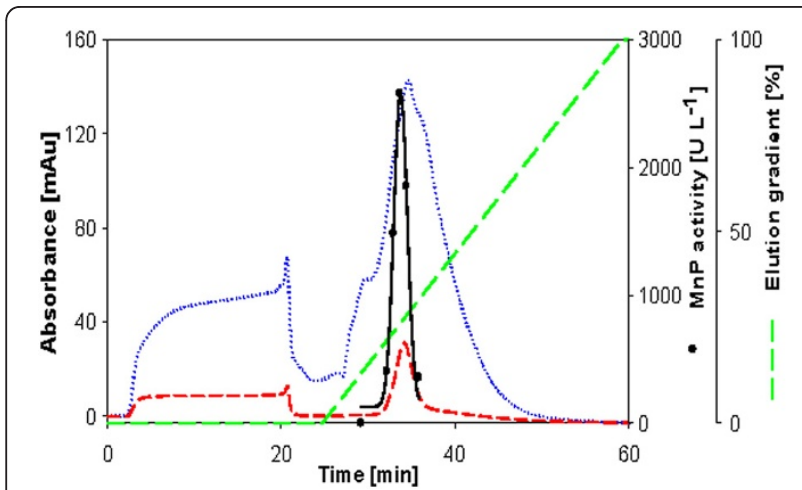

Figure 3 Anion exchange chromatogram from the purification of MnP from Bjerkandera sp. Dotted line is the absorbance at wavelength $208 \mathrm{~nm}$; Short dash line is the absorbance at wavelength $405 \mathrm{~nm}$; Long dash line is the concentration of the eluent in percentage.

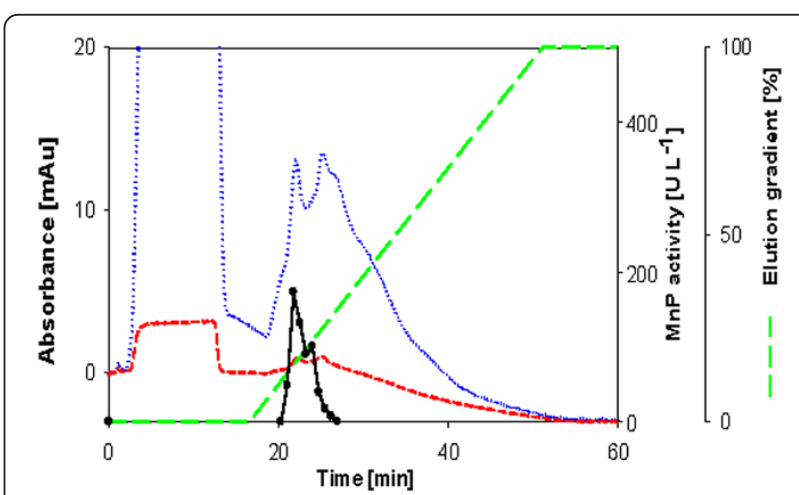

Figure 4 Anion exchange chromatogram from the purification of $\mathrm{MnP}$ from Phanerochaete chrysosporium. Symbols as in Figure 2. 


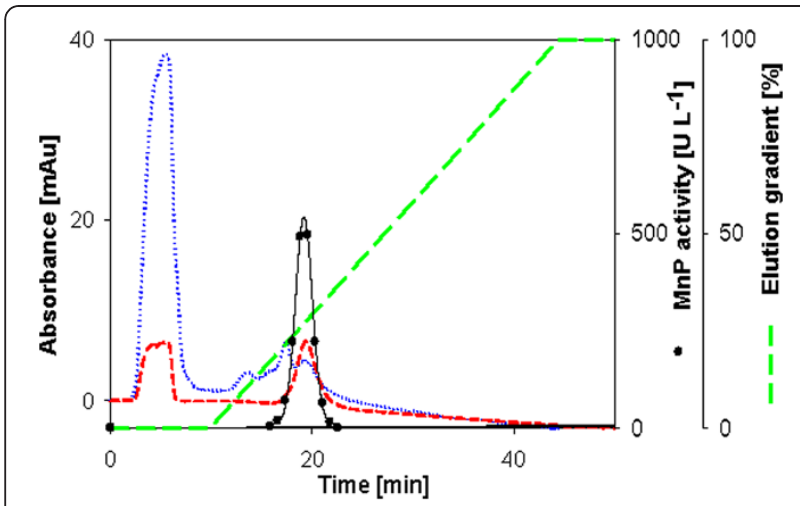

Figure 5 Anion exchange chromatogram from the purification of MnP from Physisporinus rivulosus. Symbols as in Figure 2.

measurement, the specific activity could be at least threefold higher. In addition to specific activity the stability of the purified $\mathrm{MnP}$ enzymes towards temperature, $\mathrm{pH}$ and inactivating compounds needs to be studied before candidates for recombinant production are selected. The reported specific activities are significantly lower than those previously reported for $P$. chrysosporium by Urek et al. (2004), Bjerkandera sp. by Palma et al. (2000) and Taboada-Puig et al. (2011) and for Phlebia sp. Nf b19 by Schneegaß et al. (1997)

The production of $\mathrm{MnP}$ by native producers, as also observed in this study, is limited due to relatively low maximal enzyme activities, slow growth and the sensitivity of white-rot fungi towards shear forces, difficult induction strategies and low adaptivity to submerged fermentations. In this study MnP was in most cases induced with several supplements (Mn2+, VA, Tween, Sodium malonate). However, as reported by Hakala et al. (2006), the regulation of different $\mathrm{MnP}$ isoforms can be largely dependent on the inducing compounds and nutrient (nitrogen and carbon) sources and amounts. This suggests that novel isoforms would be found by changing the culture conditions. Mn2+-ions are typically necessary inducers for

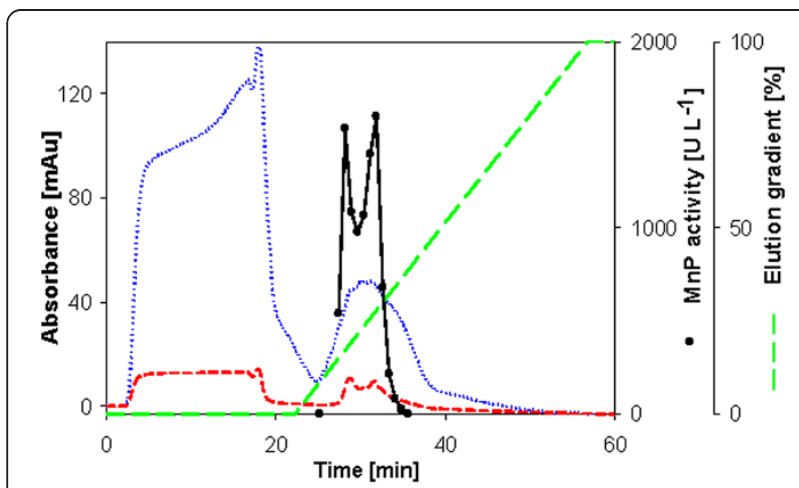

Figure 6 Anion exchange chromatogram from the purification of MnP from Phlebia radiata. Symbols as in Figure 2.

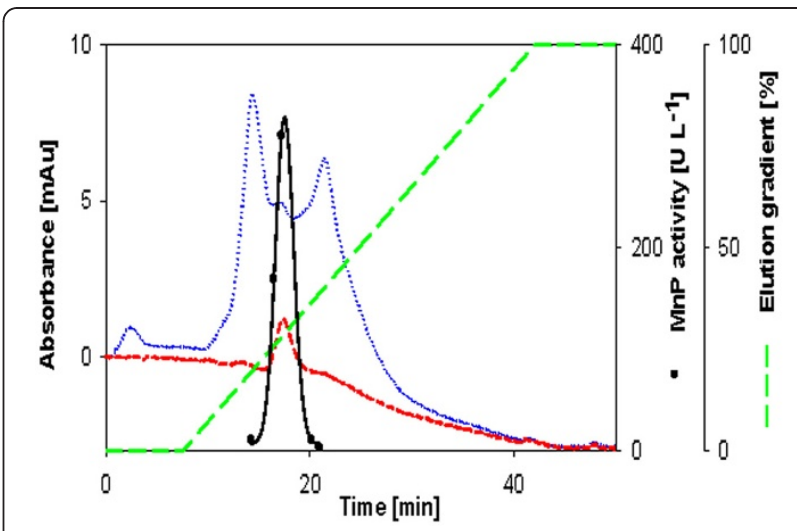

Figure 7 Anion exchange chromatogram from the purification of MnP from Phlebia sp. $\mathbf{N f}$ b19. Symbols as in Figure 2.

$\mathrm{MnP}$ production although repressive effects of $\mathrm{Mn} 2+-$ ions have also been reported (Martinez et al. 1996). Although high activity level was not the focus in this study, the culture conditions and inducing strategies (see the materials section) for this study were selected on previous literature to maximize enzyme production. Specified effects of individual inducing components cannot be separated for any strain, but clearly no $\mathrm{MnP}$ was produced before inducing components were added.

In recombinant $\mathrm{MnP}$ processes with Pichia pastoris (Jiang et al. 2008b), Aspergillus oryzae (Stewart et al. 1996), Aspergillus niger (Conesa et al. 2000) and Echerichia coli (Whitwam et al. 1995; Whitwam \& Tien 1996) production of high amounts of active protein has been a problem. These processes suffer from incorrect protein folding, insufficient heme synthesis and heme incorporation. However, MnP yield might be significantly increased with the right combination of recombinant enzyme, production host, promoter system, protein secretion system and optimized process conditions. Jiang et al. (2008b) also suspected that $P$. pastoris lacks the proper heme escorts and reseptors to transport exogenous heme to the site of MnP synthesis. This problem might be relieved by inserting the genes for such heme transport from e.g. Shigella (S.) dysenteriae (Mills \& Payne 1995). S. dysenteriae is a known pathogen causing shigellosis, which would make the GMO rating of the recombinant strain difficult. On the other hand $P$. pastoris synthesizes large amounts of a homologous heme-containing catalase protein under alchohol oxidase (AOX) promoted recombinant expression. Thus gene expression under AOX promoter might be beneficial for MnP production due to the added need for heme synthesis inside the cells. Coprinus cinereus produces a class II excreted fungal peroxidase (CiP) that readily oxidizes phenols, but is unable to oxidize veratryl alcohol or Mn2+-ions (Hofrichter et al. 2010). This enzyme is successfully produced in a recombinant process using P. pastoris (Kim et al. 2009a) with high 
Table 1 Purification of MnP isoenzymes from Bjerkandera sp. (A), Phanerochaete chrysosporium (B), Physisporinus rivulosus (C), Phlebia radiata (D) and Phlebia sp. Nf b19 (E)

\begin{tabular}{|c|c|c|c|c|c|c|}
\hline Activity [U] & Protein [mg] & Specific activity [U/mg] & $\begin{array}{l}\text { Activity protein } \\
\text { absorbance ratio } \\
{\left[\mathrm{UL}^{-1} \text { absorbance }\right.} \\
\left.\text { at } 280 \mathrm{~nm}^{-1}\right]\end{array}$ & Yield [\%] & Purification fold & Size of $\mathrm{MnP}[\mathrm{kDa}]$ \\
\hline
\end{tabular}

\begin{tabular}{|c|c|c|c|c|c|c|c|}
\hline A & & & & & & & \\
\hline Culture fluid & 38.0 & 2.9 & 13.3 & & 100 & 1.0 & \\
\hline Ultrafiltration & 19.8 & 2.6 & 7.6 & & 52.2 & 0.6 & \\
\hline Mono Q BSMnP1 & 15.3 & 0.5 & 32.3 & 18 & 40.2 & 2.4 & 45 \\
\hline B & & & & & & & \\
\hline Culture fluid & 38.7 & 1.447 & 26.7 & & 100 & 1.0 & \\
\hline$\underline{\text { Ultrafiltration }}$ & 6.9 & 0.403 & 17.0 & & 17.7 & 0.6 & \\
\hline Mono Q PCMnP1 & 1.1 & 0.005 & 200.5 & 13 & 2.8 & 7.5 & 45 \\
\hline Mono Q PCMnP2 & 0.4 & 0.013 & 33.0 & 8 & 1.1 & 1.2 & 45 \\
\hline C & & & & & & & \\
\hline Culture fluid & 36.6 & 2.685 & 13.6 & & 100 & 1.0 & \\
\hline Ultrafiltration & 7.7 & 0.278 & 27.6 & & 20.9 & 2.0 & \\
\hline Mono Q PRMnP1 & 2.3 & 0.026 & 88.6 & 122 & 6.2 & 6.5 & 50 \\
\hline D & & & & & & & \\
\hline Culture fluid & 52.0 & 4.669 & 11.2 & & 100 & 1.0 & \\
\hline Ultrafiltration & 24.6 & 2.713 & 9.1 & & 47.2 & 0.8 & \\
\hline Mono QPradMnP1 & 5.8 & 0.245 & 23.7 & 33 & 11.1 & 2.1 & 50 \\
\hline Mono Q PradMnP2 & 4.0 & 0.199 & 19.9 & 21 & 7.6 & 1.8 & 50 \\
\hline Mono Q PradMnP3 & 7.2 & 0.234 & 30.8 & 33 & 13.8 & 2.8 & 50 \\
\hline $\mathrm{E}$ & & & & & & & \\
\hline Culture fluid & 7.1 & 0.671 & 10.6 & & 100 & 1.0 & \\
\hline Ultrafiltration & 3.4 & 0.511 & 6.6 & & 46.9 & 0.6 & \\
\hline Mono Q NFMnP1 & 0.7 & 0.012 & 55.2 & 67 & 9.3 & 5.2 & 49 \\
\hline
\end{tabular}

productivities (peroxidase activity over $1200 \mathrm{U} \mathrm{ml-1}$ and total protein over $1.6 \mathrm{~g} \mathrm{l}-1$ ) and is also sold as a commercial enzyme by Novozymes (Baylase ${ }^{\circledR}$ ). The productivity of this heme-containing peroxidase was optimized by host and expression promoter selection (Kim et al. 2009b). Highest productivities were obtained by using the AOX promoter with a fast methanol utilization strain (Mut+) of $P$. pastoris. This supports the theory, that inducing the methanol utilization pathway in a production host can promote the recombinant production of heme-containing peroxidases. Commercially available MnP (from Phlebia sp. Nf b19) and VP (from Bjerkandera adusta) from Jena Bioscience $\mathrm{GmbH}$ are native enzymes and overly expensive for any kind of industrial use.

In this study several well known MnP enzymes were compared. MnP and laccase and their regulation in P. rivulosus has been well characterized by Hakala et al. (2005 \& 2006). The Differential regulation of MnP isoforms in $P$. rivulosus was also noted in these articles. In this study only one $\mathrm{MnP}$ from $P$. rivulosus is characterized, but this may very well be a group of $\mathrm{MnP}$ isoenzymes with approximately the same isoelectric points and molecular sizes. In characterization studies by Hildén et al. (2008), the MnP2 enzyme from Phlebia sp. Nf b19 showed a 96\% amino acid identity to the MnP2 enzyme of $P$. radiata in the primary structure. In this study the specific activities and sizes of the MnP enzymes produced by these related fungal strains were in the same range. Even in growth and $\mathrm{MnP}$ production these strains showed similarities (extremely slow growth and late onset of MnP production). Hildén et al. (2005) describe two MnP enzymes from $P$. radiata that are different in their primary structure, intron amount, length and crystal structure. The other isoenzyme being structurally related to LiP, but having an alanine residue instead of tryptophan while still having a conserved Mn2+-binding site. In this study three MnPs from $P$. radiata were separated, but they seemed to be highly similar in size and specific activity for Mn2+ oxidation.

Many technical applications for MnP have been reported with promising results. The utilization of the enzyme is still dependent on a cost-effective recombinant production process and possibly the discovery of more robust novel isoenzymes or modifications of the 
currently known ones. Furthermore, optimization of enzymatic treatment processes for various technical lignins (Vishtal \& Kraslawski 2011), paper pulps (Maijala et al. 2008; Xu et al. 2010) and organopollutants (Sack et al. 1997 ) with proper process conditions and co-oxidants will probably increase the interest in MnP. Delignification of pinewood sawdust using a $\mathrm{MnP}$ treatment in this study was relatively inefficient. The use of several co-oxidants and other enzymes involved in biological ligninolysis may help to achieve more thorough enzymatic delignification demonstrated by many $\mathrm{MnP}$ producing and LiP-negative white-rot fungi (Hammel \& Cullen 2008). In previous laboratory experiments by Hofrichter et al. (1998) and Kapich et al. (1999) Mineralization and solubilization of synthetic (14C-labeled) large molecular weight lignin by $\mathrm{MnP}$ has been reported. These and various other studies suggest that isolated $\mathrm{MnP}$ enzymes can be used to delignify biomasses. However, for now the utilization of class II peroxidases to degrade polluting substances in soils is technically more appealing.

\section{Competing interests}

The authors declare that they have no competing interests.

\section{Acknowledgements}

The authors would like to thank the funding partners in this research project. Also the support from the finnish geo- and water technology support foundation (MVIT) for the writing part of this work is acknowledged.

Received: 22 August 2012 Accepted: 19 November 2012

Published: 29 November 2012

\section{References}

Bharagava RN, Chandra R, Rai V (2009) Isolation and characterization of aerobic bacteria capable of the degradation of synthetic and natural melanoidins from distillery effluent. World J Microbiol Biotechnol 25:737-744

Bonnarme P, Jeffries T (1990) Mn(II) regulation of lignin peroxidases and manganese-dependent peroxidases from lignin-degrading white rot fungi. Appl Environ Microbiol 56:210-217

Conesa A, van den Hondel C, Punt P (2000) Studies on the production of fungal peroxidases in Aspergillus niger. Appl Environ Microbiol 66:3016-3023

Floudas D et al (2012) The Paleozoic origin of enzymatic lignin decomposition reconstructed from 31 fungal genomes. Science 336(6089):17151719

Hakala T, Lundell T, Galkin S, Maijala P, Kalkkinen N, Hatakka A (2005) Manganese peroxidases, laccases and oxalic acid from the selective white-rot fungus Physisporinus rivulosus grown on spruce wood chips. Enzyme Microb Tech 36:461-468

Hakala T, Hildén K, Maijala P, Olsson C, Hatakka A (2006) Differential regulation of manganese peroxidases and characterization of two variable MnP encoding genes in the white-rot fungus Physisporinus rivulosus. Appl Microbiol Biotechnol 73:839-849

Hammel K, Cullen D (2008) Role of fungal peroxidases in biological ligninolysis. Curr Opin Plant Biol 11:349-355

Hatakka A, Uusi-Rauva A (1983) Degradation of 14C-labelled poplar wood lignin by selected white-rot fungi. Eur J Appl Microbiol Biotechnol 17:235-242

Hildén K, Martinez A, Hatakka A, Lundell T (2005) The two manganese peroxidases Pr-MnP2 and Pr-MnP3 of Phlebia radiata, a lignin-degrading basidiomycete, are phylogenetically and structurally divergent. Fungal Genet Biol 42:403-419

Hildén K, Bortfeldt R, Hofrichter M, Hatakka A, Lundell T (2008) Molecular characterization of the basidiomycete isolate Nematoloma frowardii b19 and its manganese peroxidase places the fungus on the corticioid genus Phlebia. Microbiology 154:2371-2379

Hofrichter M, Vares T, Scheibner K, Galkin S, Sipilä J, Hatakka A (1999) Mineralization and solubilization of synthetic lignin by manganese peroxidases from Nematoloma frowardii and Phlebia radiata. J Biotechnol 67:217-228

Hofrichter M, Lundell T, Hatakka A (2001) Conversion of milled pine wood by manganese peroxidase from Phlebia radiata. Appl Environ Microbiol 67:4588-4593

Hofrichter M, Scheibner K, Schneegass I, Fritsche W (1998) Enzymatic combustion of aromatic and aliphatic compounds by manganese peroxidase from Nematoloma frowardii. Appl Environ Microbiol 64:399-404

Hofrichter M (2002) Review: lignin conversion by manganese peroxidase (MnP). Enzyme Microb Technol 30:454-466

Hofrichter M, Ullrich R, Pecyna M, Liers C, Lundell T (2010) New and classic families of secreted fungal heme peroxidases. Appl Microbiol Biotechnol 87:871-897

Irie T, Honda Y, Watanabe T, Kuwahara M (2001) Homologous expression of recombinant manganese peroxidase genes in ligninolytic fungus Pleurotus ostreatus. Appl Microbiol Biotechnol 55:566-570

Jiang F, Kongsaeree P, Schilke K, Lajoie C, Kelly C (2008a) Effects of pH and temperature on recombinant manganese peroxidase production and stability. Appl Biochem Biotechnol 146:15-27

Jiang F, Kongsaeree P, Charron R, Lajoie C, Xu H, Scott G, Kelly C (2008b) Production and separation of manganese peroxidase from heme amended yeast cultures. Biotechnol Bioeng 99:540-549

Jimenez-Tobon G, Kurzatkowski W, Rozbicka B, Solecka J, Pocsi I, Penninckx M (2003) In situ localization of manganese peroxidase production in mycelial pellets of Phanerochaete chrysosporium. Microbiology-Sgm 149:3121-3127

Johnson T, Pease EA, Li J, Tien M (1992) Production and characterization of recombinant lignin peroxidase isozyme $\mathrm{H} 2$ from Phanerochaete chrysosporium using recombinant baculovirus. Arc Biochem Biophys 296(2):660-666

Kamitsuji H, Honda Y, Watanabe T, Kuwahara M (2004) Production and induction of manganese peroxidase isozymes in a white-rot fungus Pleurotus ostreatus. Appl Microbiol Biotechnol 65:287-294

Kapich A, Hofrichter M, Vares T, Hatakka A (1999) Coupling of manganese peroxidase-mediated lipid peroxidation with destruction of nonphenolic lignin. Biochem Bioph Res Co 259(1):212-219, Model Compounds and 14CLabeled Lignins

Kim S, Lee J, Won K, Kim Y, Song B (2009a) Functional expression of Coprinus cinereus peroxidase in Pichia pastoris. Process Biochem 44(7):731-735

Kim S, Lee J, Kim Y, Song B (2009b) Optimization of the functional expression of Coprinus cinereus peroxidase in pichia pastoris by varying the host and promoter. J Microbiol Biotechn 19(9):966-971

Lankinen P, Hilden K, Aro N, Salkinoja-Salonen M, Hatakka A (2005) Manganese peroxidase of Agaricus bisporus: grain bran-promoted production and gene characterization. Appl Microbiol Biotechnol 66:401-407

Li J, Gellerstedt G, Toven K (2009) Steam explosion lignins; their extraction, structure and potential as feedstock for biodiesel and chemicals. Biores Technol 100:2556-2561

Li D, Youngs H, Gold M (2001) Heterologous expression of a thermostable manganese peroxidase from Dichomitus squalens in Phanerochaete chrysosporium. Arch Biochem Biophys 385:348-356

Maijala P, Kleen M, Westin C, Poppius-Levlin K, Herranen K, Lehto JH, Reponen P, Mäentausta O, Mettala A, Hatakka A (2008) Biomechanical pulping of softwood with enzymes and white-rot fungus Physisporinus rivulosus. Enzyme Microb Technol 43:169-177

Martinez M, RuizDuenas F, Guillen F, Martinez A (1996) Purification and catalytic properties of two manganese peroxidase isoenzymes from Pleurotus eryngii. Eur J Biochem 237:424-432

Mayfield M, Kishi K, Alic M, Gold M (1994) Homologous expression of recombinant manganese peroxidase in Phanerochaete chrysosporium. Appl Environ Microbiol 60:4303-4309

Mills M, Payne S (1995) Genetics and regulation of heme iron transport in Shigella dysenteriae and detection of an analogous system in Echerichia coli O157:H. J Bacteriol 177:3004-3009

Mishra M, Thakur I (2010) Isolation and characterization of alkalotolerant bacteria and optimization of process parameters for decolorization and detoxification of pulp and paper mill effluent by Taguchi approach. Biodegradation 21:967-978

Moilanen A, Lundell T, Vares T, Hatakka A (1996) Manganese and malonate are individual regulators for the production of lignin and manganese peroxidase isozymes and in the degradation of lignin by Phlebia radiata. Appl Microbiol Biotechnol 45:792-799

Moreira P, Duez C, Dehareng D, Antunes A, Almeida-Vara E, Frère J et al (2005) Molecular characterisation of a versatile peroxidase from a Bjerkandera strain. J Biotech 118(4):339-352 
Moreira M, Feijoo G, Canaval J, Lema J (2003) Semipilot-scale bleaching of Kraft pulp with manganese peroxide. Wood Sci Technol 37:117-123

Moreira M, Sierra-Alvarez R, Lema JM, Feijoo G, Field J (2001) Oxidation of lignin in eucalyptus Kraft pulp by manganese peroxidase from Bjerkandera $s p$ strain BOS55. Biores Technol 78:71-79

Nuske J, Scheibner K, Dornberger U, Ullrich R, Hofrichter M (2002) Large scale production of manganese-peroxidase using agaric white-rot fungi. Enzyme Microb Technol 30:556-561

Paice M, Reid I, Bourbonnais R, Archibald F, Jurasek L (1993) Manganese peroxidase, produced by Trametes-versicolor during pulp bleaching, demethylates and delignifies Kraft pulp. Appl Environ Microbiol 59:260-265

Palma C, Martínez A, Lema J, Martínez M (2000) Different fungal manganeseoxidizing peroxidases: a comparison between Bjerkandera sp. And Phanerochaete chry-sosporium. J Biotechnol 77:235-245

Pease E, Aust S, Tien M (1991) Heterologous expression of active manganese peroxidase from Phanerochaete chrysosporium using the baculovirus expression system. Biochem Biophys Research Comm 179:897-903

Perie F, Gold M (1991) Manganese regulation of manganese peroxidase expression and lignin degradation by the white-rot fungus Dichomitussqualens. Appl Environ Microbiol 57:2240-2245

Petruccioli M, Frasconi M, Quaratino D, Covino S, Favero G, Mazzei F, Federici F, D'Annibale A (2009) Kinetic and redox properties of MnP II, a major manganese peroxidase isoenzyme from Panus tigrinus CBS 577.79. J Biol Inorg Chem 14:1153-1163

Reading NS, Aust SD (2001) Role of disulfide bonds in the stability of recombinant manganese peroxidase. Biochemistry 40:8161-8168

Sack U, Hofrichter M, Fritsche W (1997) Degradation of polycyclic aromatic hydrocarbons by manganese peroxidase of Nematoloma frowardii. FEMS Microbiol Lett 152:227-234

Schneegaß I, Hofrichter M, Scheibner K, Fritsche W (1997) Purification of the main manganese peroxidase isoenzyme $\mathrm{MnP2}$ from the white-rot fungus Nematoloma frowardii b19. Appl Microbiol Biotechnol 48:602-605

Singh D, Zeng J, Chen S (2011) Increasing manganese peroxidase productivity of Phanerochaete chrysosporium by optimizing carbon sources and supplementing small molecules. Lett Appl Microbiol 53:120-123

Silva E, Martins S, Milagres A (2008) Extraction of manganese peroxidase produced by Lentinula edodes. Biores Technol 99:2471-2475

Sklenar J, Niku-Paavola M-L, Santos S, Man P, Kruus K, Novotny C (2010) Isolation and characterization of novel pl $4.8 \mathrm{MnP}$ isoenzyme from white-rot fungus Irpex lacteus. Enzyme Microb Technol 46:550-556

Steffen K, Hofrichter M, Hatakka A (2002) Purification and characterization of manganese peroxidases from the litter-decomposing basidiomycetes Agrocybe praecox and Stropharia coronilla. Enzyme Microb Technol 30:550-555

Stewart P, Whitwam R, Kersten P, Cullen D, Tien M (1996) Efficient expression of a Phanerochaete chrysosporium manganese peroxidase gene in Aspergillus oryzae. Appl Environ Microbiol 62:860-864

Sundaramoorthy M, Kishi K, Gold M, Poulos T (1997) Crystal structures of substrate binding site mutants of manganese peroxidase. J Biol Chem 272:17574-17580

Sutherland G, Zapanta L, Tien M, Aust S (1997) Role of calcium in maintaining the heme environment of manganese peroxidase. Biochemistry 36:36543662

Susla M, Novotny C, Erbanova P, Svobodova K (2008) Implication of Dichomitus squalens manganese-dependent peroxidase in Dye decolorization and cooperation of the enzyme with laccase. Folia Microbiol 53:479-485

Swamy J, Ramsay J (1999) Effects of Mn2+ and NH4+: concentrations on laccase and manganese peroxidase production and Amaranth decoloration by Trametes versicolor. Appl Microbiol Biotechnol 51:391-396

Taboada-Puig R, Lú-Chau T, Moreira M, Feijoo G, Martínez M, Lema J (2011) A new strain of Bjerkandera sp. production, purification and characterization of versatile peroxidase. World J Microbiol Biotechnol 27:115-122

Tien M, Kirk T (1988) Lignin peroxidase of Phanerochaete chrysosporium. Methods Enzym 161:238-248

Urek R, Pazarlioglu N (2004) Purification and partial characterization of manganese peroxidase from immobilized Phanerochaete chrysosporium. Process Biochem 39:2061-2068

Vares T, Kalsi M, Hatakka A (1995) Lignin peroxidases, manganese peroxidases, and other ligninolytic enzymes produced by Phlebia radiata during solidstate fermentation of wheat straw. Appl Environ Microbiol 61:3515-3520
Vishtal A, Kraslawski A (2011) Challenges in industrial applications of technical lignins. BioResources 6:3547-3568

Wang P, Hu X, Cook S, Begonia M, Lee K, Hwang H-M (2008) Effect of culture conditions on the production of ligninolytic enzymes by white rot fungi Phanerochaete chrysosporium (ATCC 20696) and separation of its lignin peroxidase. World J Microbiol Biotechnol 24:2205-2212

Wang Y, Vazquez-Duhalt R, Pickard M (2001) Effect of growth conditions on the production of manganese peroxidase by three strains of Bjerkandera adusta. Can J Microbiol 47:277-282

Wariishi H, Valli K, Gold M (1992) Manganese(II) oxidation by manganese peroxidase from the basidiomycete Phanerochaete chrysosporium - kinetic mechanism and role of chelators. J Biol Chem 267:23688-23695

Whetten R, Sederoff R (1995) Lignin biosynthesis. Plant Cell 7:1001-1013

Whitwam R, Tien M (1996) Heterologous expression and reconstitution of fungal Mn peroxidase. Arch Biochem Biophys 333:439-446

Whitwam R, Gazarian I, Tien M (1995) Expression of fungal Mn peroxidase in Escherichia coli and refolding to yield active enzyme. Biochem Biophys Res Commun 216:1013-1017

Xu H, Scott G, Jiang F, Kelly C (2010a) Recombinant manganese peroxidase (rMnP) from Pichia pastoris. Part 1: Kraft pulp delignification. Holzforschung 64:137-143

Xu H, Scott G, Jiang F, Kelly C (2010b) Recombinant manganese peroxidase (rMnP) from Pichia pastoris. Part 2: application in TCF and ECF bleaching. Holzforschung 64:145-151

Yadav S, Chandra R, Rai V (2011) Characterization of potential MnP producing bacteria and its metabolic products during decolourisation of synthetic melanoidins due to biostimulatory effect of D-xylose at stationary phase. Process Biochem 46(9):1774-1784

doi:10.1186/2191-0855-2-62

Cite this article as: Järvinen et al:: Screening of white-rot fungi manganese peroxidases: a comparison between the specific activities of the enzyme from different native producers. AMB Express 2012 2:62.

\section{Submit your manuscript to a SpringerOpen ${ }^{\circ}$ journal and benefit from:}

- Convenient online submission

- Rigorous peer review

- Immediate publication on acceptance

- Open access: articles freely available online

- High visibility within the field

- Retaining the copyright to your article

Submit your next manuscript at $>$ springeropen.com 